\title{
Clonal reproduction and population genetic structure of grape phylloxera, Daktulosphaira vitifoliae, in Australia
}

\author{
AM Corrie ${ }^{1}$, RH Crozier ${ }^{2}$, R Van Heeswijck ${ }^{3}$ and AA Hoffmann ${ }^{1}$ \\ ${ }^{1}$ Centre for Environmental Stress and Adaptation Research, La Trobe University, Bundoora, Vic. 3086, Australia; ${ }^{2}$ Department of \\ Zoology and Tropical Ecology, James Cook University, Townsville, QLD 4811, Australia; ${ }^{3}$ Department of Horticulture,Viticulture \\ and Oenology, University of Adelaide, PMB 1 Glen Osmond, SA 5064, Australia
}

The grape phylloxera, Daktulosphaira vitifoliae, is a viticultural pest that in the past has devastated vineyards worldwide, yet little is known about this insect's biology. The genetic structure of Australian populations of grape phylloxera and its mode of reproduction were studied following the development of four polymorphic microsatellite loci. Insects were collected from 28 vineyards, with a total of 361 insects included in the study. The majority of vineyards were infested by functionally parthenogenetic lineages of grape phylloxera that inhabit the root system and there was little support for the traditionally described holocyclic life cycle for this species. Clonal diversity was limited in all of the vineyard regions, with the exception of the Rutherglen region. A multiple founder scenario or occasional sex may contribute to diversity within the Rutherglen region. Leaf galling populations comprised classes distinct from the common genotypic classes identified on the roots, suggesting limited exchange between these groups. Implications for the management of $D$. vitifoliae are discussed.

Heredity (2002) 88, 203-211. DOI: 10.1038/sj/hdy/6800028

Keywords: Daktulosphaira vitifoliae; clonal reproduction; microsatellite; parthenogenesis; grape phylloxera; genetic diversity

\section{Introduction}

Grape phylloxera, Daktulosphaira vitifoliae, is an important pest of members of the genus Vitis, specifically the European grapevine $V$. vinifera. Its interaction with the root system of $V$. vinifera is known to result in severe yield reduction and eventual vine death. The economic impact of D. vitifoliae was first realized during the 1860 s when it was inadvertently introduced to the European grapegrowing regions from its native North America. Grape phylloxera has subsequently spread to the majority of grape-producing countries. To reduce the impact of grape phylloxera, native American Vitis species have been used in breeding strategies to develop resistant and/or tolerant rootstocks from the late 1800s, and this is now the principal management strategy employed (Ordish, 1974). Despite the widespread use of rootstocks, the insect persists in all major grape-growing countries.

Members of the superfamily Aphidoidea (Homoptera), which include the Phylloxeridae, Aphididae, and Adelgidae, have complex life cycles incorporating various mating systems. These include sexual reproduction with subsequent apomictic parthenogenetic reproduction through the suppression of meiosis (holocyclic), obligate parthenogenetic reproduction (anholocyclic), and populations with varying degrees of commitment to sexuals, including the production of only males (androcyclic) or the production of some males and females whilst par-

Correspondence: A Corrie, Centre for Environmental Stress and Adaptation Research, La Trobe University, Bundoora, Victoria 3083, Australia. E-mail: A.Corrie@latrobe.edu.au

Received 26 April 2001; accepted 10 October 2001 thenogenetic production is continued (mixed strategy) (Moran, 1992; Hales et al, 1997; Dedryver et al, 1998).

Holocyclic reproduction is considered the primary life cycle mode of D. vitifoliae (Downie and Granett, 1998; Granett et al, 2001). The insect has only one host type, members of the genus Vitis. Parthenogenetic reproduction is proposed to occur on the roots and leaves of Vitis in the spring and summer months. During autumn, the population on the roots exhibits a polyphenic shift to the production of alates (winged insect). The alates disperse above ground and produce asexually the male and female sexuals that subsequently mate and lay the overwintering eggs. The female fundatrix, which hatches from the sexual egg during the following spring, moves to the leaves of the grapevine and forms a leaf gall, where parthenogenetic reproduction begins again. There is subsequent movement of parthenogenetic individuals back to the root system during the summer months. In California, grape phylloxera is considered to be present mainly on the root system and is thought to be functionally parthenogenetic due to the rarity of leaf galls and the observation that first instars can overwinter on the root system (Davidson and Nougaret, 1921).

Verification of the life cycle in commercial vineyards has been difficult because of problems in observing and sampling sexual morphs from the field (Buchanan, 1990) and the absence of leaf galling on the European grape $V$. vinifera. Whilst leaf galling occurs on some natural hosts (ie some American Vitis species and their hybrids), there is an incompatible interaction between the insect and leaves of $V$. vinifera. In Europe, grape phylloxera populations causing leaf galls are widely distributed on Vitis hybrids and sex is presumed to occur (Forneck et al, 
2000). Alates have been sampled from field grapevines and sexuals observed in laboratory situations, but neither observation confirms the completion of the sexual cycle in the vineyard nor the impact of the sexual stages on the incidence of leaf galls (Adcock, 1902; Davidson and Nougaret, 1921; Forneck et al, 2001).

Studies of the genetic structure of D. vitifoliae in Europe have suggested that sex does occur in the field but that the incidence may vary between northern and southern Europe. This hypothesis was based on analysis of amplified fragment length polymorphism (AFLP) markers that revealed extensive polymorphism within and between populations, and a relatively greater level of genetic diversity in northern regions (Forneck et al, 2000). However, the dominant inheritance patterns of AFLP markers makes it difficult to quantify the contribution of meiotic processes to the observed genetic variation.

DNA markers based on microsatellite loci should be more useful for characterization of the D. vitifoliae life cycle. As codominant and highly variable DNA markers, they provide a powerful system for unraveling life history traits, particularly the occurrence of sex (reviewed in Sunnucks et al, 1997; Hales et al, 1997). They have been used in life cycle studies of members of the Aphididae family, resulting in high level resolution of reproductive mode and exploration of genetic relationships, including those of clonal lineages (Sunnucks et al, 1996, 1997; Fuller et al, 1999; Simon et al, 1999; Wilson et al, 1999).

Here, microsatellite markers are used to investigate the mode of reproduction and genetic structure of grape phylloxera populations in South Eastern Australia. Since its discovery in Australia in 1877, D. vitifoliae has been identified, and contained, within five geographic regions (Figure 1) through internal quarantine measures. Australia is unique in its approach to grape phylloxera man-

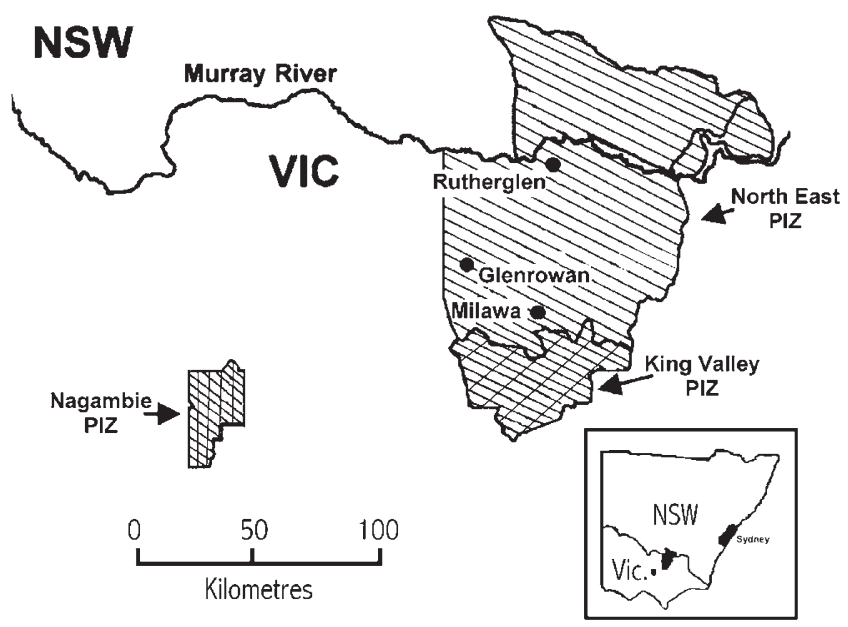

Figure 1 Daktulosphaira vitifoliae infested regions and sampling sites in Victoria (VIC) and New South Wales (NSW), Australia. Areas with known $D$. vitifoliae infestations are termed Phylloxera Infestation Zones (PIZs). The shaded regions indicate the three PIZs from which samples were collected in Victoria; Nagambie, King Valley, and North East. The Rutherglen, Glenrowan and Milawa collection sites are all located within north east Victoria PIZ. No insects were found in vineyards from the other Victorian PIZ, Mooroopna (location not shown). The samples collected from NSW are located at Orchard Hills, near Sydney. Table 1 lists the regional location of the vineyards from which $D$. vitifoliae samples were collected. agement, with a strong reliance on quarantine and the majority of vineyards not utilizing rootstocks. Based on the microsatellite DNA marker patterns obtained, three questions were posed: (i) what is the incidence of sexual and parthenogenetic life cycle strategies?; (ii) do root populations contribute to genotypes observed in leaf galling populations and vice versa?; and (iii) is there genetic diversity within and between regions and can this be related to the infestation history of grape phylloxera?

\section{Materials and methods}

\section{Insect collection}

Root samples were collected in January 2000 from 28 vineyards, previously reported as infested with $D$. vitifoliae (Buchanan, 1987). The vineyards were located within four of the five Phylloxera Infestation Zones (PIZs) located in Victoria and New South Wales (NSW), Australia (Figure 1). A vineyard was defined as a single viticultural operation, owned and operated by a particular company within a region but often varying in size (Table 1).

Under the traditional life cycle of grape phylloxera, summer root samples should be produced by parthenogenesis following sexual reproduction and parthenogenesis over the preceding winter. To increase the likelihood of collecting recombinant offspring from the putative sexual phase, only single specimens were collected from the roots of an individual vine. The distance between vine samples within a vineyard varied from $10 \mathrm{~m}$ up to $3 \mathrm{~km}$ in three (NA-1, RU-1, ML-1) of the larger vineyards. The total number of samples obtained and their location within a vineyard was dependent on both the density and distribution of the infestations (ie, how readily insects were found). Both infestation density and distribution can be influenced by infestation age, soil type, host genotype, and vine health (Buchanan, 1987). Where possible, insects were collected from the root systems of different $V$ itis genotypes within an individual vineyard (Table 1).

During the same collection period, leaf samples were also obtained from three vineyards, each in a different region. Only one female was collected from a single leaf gall because under the traditional life cycle all females within a gall were expected to have been produced by parthenogenesis, whereas founders of the different galls should be the product of sexual reproduction. Up to 10 galls were sampled from one leaf. In Rutherglen, the vineyard contained 20 adjacent non-grafted rootstocks (Vitis genotype unknown) and galls were collected at random from the leaves of 10 vines. In Milawa, galls were collected from the leaves of four non-grafted Schwarzmann $(V$. rupestris $\times V$. riparia $)$ rootstocks. In Glenrowan, galls were collected from within a grafted vineyard block, where some of the rootstocks (Vitis genotype unknown) had produced suckers. Leaf galls were collected from five vines, each separated by a distance of over $30 \mathrm{~m}$, although other vines with leaf galls were scattered throughout this block. Root samples were also collected from two vines exhibiting leaf galls in each of the three vineyards. These samples were included in the root samples. All insects were stored in $100 \%$ ethanol at $-20^{\circ} \mathrm{C}$. 
Table 1 Geographic region, and vine host origin of the Daktulosphaira vitifoliae samples collected in January 2000 from Australian vineyards. The year(s) an infestation was first observed within a region is indicated in brackets. The approximate vineyard size is also indicated

\begin{tabular}{|c|c|c|c|c|}
\hline \multirow{2}{*}{$\begin{array}{l}\text { Geographic region } \\
\text { (year infestation first } \\
\text { observed) }\end{array}$} & \multirow{2}{*}{$\begin{array}{l}\text { Vineyard } \\
\text { Code }\end{array}$} & \multirow{2}{*}{$\begin{array}{l}\text { Approximate size of } \\
\text { vineyard (hectares) }\end{array}$} & \multicolumn{2}{|r|}{ Samples sourced from: } \\
\hline & & & Plant component & Grape vine type \\
\hline Glenrowan (1902-1920) & $\begin{array}{l}\text { GR-1 } \\
\text { GR-3 } \\
\text { GR-4 }\end{array}$ & $\begin{array}{l}50-80 \\
10-30 \\
10-30\end{array}$ & $\begin{array}{l}\text { Root and leaf } \\
\text { Root } \\
\text { Root }\end{array}$ & $\begin{array}{l}\text { AxR\#1, unknown } \\
V . \text { vinifera } \\
V . \text { vinifera, AxR\#1 }\end{array}$ \\
\hline King Valley (1991-1995)b & $\begin{array}{l}\text { CH-1 } \\
\text { WF-1 } \\
\text { WL-1 } \\
\text { WL-2 }\end{array}$ & $\begin{array}{l}30-50 \\
10-30 \\
30-50 \\
10-30\end{array}$ & $\begin{array}{l}\text { Root } \\
\text { Root } \\
\text { Root } \\
\text { Root }\end{array}$ & $\begin{array}{l}V . \text { vinifera } \\
V . \text { vinifera } \\
V . \text { vinifera } \\
V . \text { vinifera }\end{array}$ \\
\hline Milawa (1902-1920)a & $\begin{array}{l}\text { ML-1 } \\
\text { ML-3 }\end{array}$ & $\begin{array}{c}50-80 \\
<10\end{array}$ & $\begin{array}{l}\text { Root and leaf } \\
\text { Root }\end{array}$ & $\begin{array}{l}V . \text { vinifera, AxR\#1, 1202C, Schwarzmann } \\
V . \text { vinifera }\end{array}$ \\
\hline Nagambie $(1897)^{c}$ & $\begin{array}{l}\text { NA-1 } \\
\text { NA-2 } \\
\text { NA-3 } \\
\text { NA-5 } \\
\text { NA-6 }\end{array}$ & $\begin{array}{l}110-140 \\
110-140 \\
\quad<10 \\
<10 \\
<10\end{array}$ & $\begin{array}{l}\text { Root } \\
\text { Root } \\
\text { Root } \\
\text { Root } \\
\text { Root }\end{array}$ & $\begin{array}{l}V . \text { vinifera, AxR\#1 } \\
V . \text { vinifera } \\
V . \text { vinifera } \\
V . \text { vinifera } \\
V . \text { vinifera }\end{array}$ \\
\hline Orchard Hills $(1969)^{\mathrm{d}}$ & $\begin{array}{l}\mathrm{OH}-1 \\
\mathrm{OH}-2 \\
\mathrm{OH}-3\end{array}$ & $\begin{array}{l}<10 \\
<10 \\
<10\end{array}$ & $\begin{array}{l}\text { Root } \\
\text { Root } \\
\text { Root }\end{array}$ & $\begin{array}{l}V . \text { vinifera, AxR\#1 } \\
V . \text { vinifera } \\
V . \text { vinifera }\end{array}$ \\
\hline Rutherglen (1899) ${ }^{c}$ & $\begin{array}{l}\text { RU-1 } \\
\text { RU-2 } \\
\text { RU-3 } \\
\text { RU-4 } \\
\text { RU-5 } \\
\text { RU-6 } \\
\text { RU-7 } \\
\text { RU-8 } \\
\text { RU-9 } \\
\text { RU-13 } \\
\text { RU-15 }\end{array}$ & $\begin{array}{c}50-80 \\
10-30 \\
10-30 \\
<10 \\
10-30 \\
30-50 \\
50-80 \\
50-80 \\
50-80 \\
30-50 \\
10-30\end{array}$ & $\begin{array}{l}\text { Root } \\
\text { Root } \\
\text { Root } \\
\text { Root } \\
\text { Root } \\
\text { Root } \\
\text { Root } \\
\text { Root } \\
\text { Root } \\
\text { Root and leaf } \\
\text { Root }\end{array}$ & $\begin{array}{l}\text { Schwarzmann, AxR\#1, V. vinifera, unknown } \\
\text { AxR\#1, 1309C, Schwarzmann } \\
\text { AxR\#1 } \\
\text { V. vinifera, } \\
\text { AxR\#1 } \\
\text { AxR\#1, V. vinifera, unknown } \\
V . \text { vinifera } \\
\text { Unknown } \\
\text { AxR\#1 } \\
\text { AxR\#1, unknown } \\
\text { AxR\#1, unknown }\end{array}$ \\
\hline
\end{tabular}

aCorrie et al, 1997; bBuchanan, 1990; 'Adcock, 1902; ' ${ }^{\mathrm{c}}$ Fletcher, 1984.

Cloning and amplification of microsatellites

Total DNA was extracted from grape phylloxera adults using Lin and Walker's (1996) method, with modifications as described by Corrie et al (1997), yielding approximately $5 \mu \mathrm{g}$ of DNA from 500 insects. The insects used in the DNA extraction procedure were collected from sterile in vitro cultures to ensure minimal contamination of DNA from other organisms (Kellow et al, 1999). The construction of each partial genomic library utilized $2 \mu \mathrm{g}$ of DNA digested with one of the following enzyme combinations: Library 1, MboI; Libraries 2, 3 and 4: Sau3AI/RsaI. The fragments were size-selected (200-700 bp) by agarose gel electrophoresis and ligated into either pBlueScript SK II (+) (Stratagene) or pUC19 vector (Genesearch) digested with BamHI. After transformation into E. coli strain JM109 (Promega), colonies were transferred to HyBond ${ }^{\mathrm{TM}} \mathrm{N}^{+}$nylon membranes (Amershem Pharmacia Biotech) according to standard methods (Ausubel et al, 1996) and probed by hybridization with $\left[\alpha^{33} \mathrm{P}\right]-\mathrm{dATP}(10 \mathrm{mCi} / \mathrm{ml}$; Geneworks) end-labelled oligonucleotides. The synthetic oligonucleotides $(\mathrm{CA})_{10}$, $(\mathrm{AG})_{10},(\mathrm{CCT})_{5},(\mathrm{CAC})_{5},(\mathrm{ATT})_{5},(\mathrm{ATCT})_{4}$ or $(\mathrm{TGTA})_{4}$ were used. A total of approximately 30000 recombinants were screened from the four libraries. Plasmid inserts from the putative positives were sequenced using both standard manual and automated methods. Ten clones were identified as containing nucleotide repeat regions, however only five of these contained repeat regions consisting of more than one nucleotide base or greater than six repeat units. Primer pairs based on unique non-repetitive flanking DNA sequences could only be designed for four clones, however all of these revealed polymorphisms when used in the polymerase chain reaction (PCR) on grape phylloxera genomic DNA (Table 2). The sizes of the alleles were determined using a standard sequencing reaction of the pUC19 vector (Genesearch) as the molecular weight standard ladder.

In preparation for PCR, 5\% Chelex ${ }^{\circledR} 100$ (BioRad) was used for DNA extractions from single adult females (Walsh et al, 1991). In brief, insects were placed into a sterile $0.5 \mathrm{ml}$ tube, the excess ethanol evaporated, and then ground with a pestle in liquid nitrogen, after which $60 \mu \mathrm{l} 5 \% \mathrm{Chelex}^{\circledR} 100$ and $1 \mu \mathrm{l}$ proteinase $\mathrm{K}(14 \mathrm{mg} / \mathrm{ml}$; Boehringer Mannheim) was added, followed by incubation at $56^{\circ} \mathrm{C}$ for $10-12 \mathrm{~h}$, then $92^{\circ} \mathrm{C}$ for $5 \mathrm{~min}$. DNA extractions were stored at $-20^{\circ} \mathrm{C}$.

PCR was performed in a $10 \mu \mathrm{l}$ volume containing 10 pmol of each primer pair, with the forward primer endlabeled with $\left[\alpha^{33} \mathrm{P}\right]$-dATP $(10 \mathrm{mCi} / \mathrm{ml}$; Geneworks $), 0.7$ $\mathrm{mM}$ of the four dNTPs (Biotech), $1 \mu \mathrm{l} 10 \times$ PCR buffer containing $1.5 \mathrm{mM} \mathrm{MgCl}_{2}$ (Promega), 0.8 units Taq DNA polymerase (Promega) and $2 \mu \mathrm{l}$ DNA. PCR consisted of an initial denaturation phase at $93^{\circ} \mathrm{C}$ for $2 \mathrm{~min}$, followed by 30 cycles of $93^{\circ} \mathrm{C}$ for $30 \mathrm{~s}$, annealing at the temperature indicated in Table 2 for $30 \mathrm{~s}, 72^{\circ} \mathrm{C}$ for $30 \mathrm{~s}$, with a final extension phase at $72^{\circ} \mathrm{C}$ for $3 \mathrm{~min}$. Electrophoresis of the 
Table 2 Definition of the four microsatellite loci used to determine the genotypes of the Daktulosphaira vitifoliae samples

\begin{tabular}{|c|c|c|c|c|c|}
\hline Locus name & Repeat motifa & $\begin{array}{c}\text { Genbank } \\
\text { Accession no. }\end{array}$ & $\begin{array}{l}\text { Flanking primer sequences } \\
\left(5^{\prime} \rightarrow 3^{\prime}\right)\end{array}$ & $\begin{array}{l}\text { Annealing } \\
\text { temperature }\end{array}$ & Allele sizes $(b p)$ \\
\hline DVIT1 & $(\mathrm{CA})_{9}(\mathrm{CG})_{4}$ & AY056815 & $\begin{array}{l}\text { F: CGTTCGTTCTGGTATCGTTATT } \\
\text { R: TAACGACCCGACTGAAATGTAG }\end{array}$ & $50^{\circ} \mathrm{C}$ & $\begin{array}{l}128,132,134,136, \\
138\end{array}$ \\
\hline DVIT2 & $(\mathrm{CT})_{14}(\mathrm{AT})_{16}$ & AY056816 & $\begin{array}{l}\text { F: GCTTAATTTTGTGTCTCAAGTTA } \\
\text { R: TAATGCTTCGTTTTCTAAGTGC }\end{array}$ & $47^{\circ} \mathrm{C}$ & $257,259,261,289$ \\
\hline DVIT3 & $(\mathrm{AT})_{9}(\mathrm{GT})_{11}$ & AY056817 & $\begin{array}{l}\text { F: CCAAAACAACCAAGATTTTCTCC } \\
\text { R: GATCCAAACTATGACAAACACCC }\end{array}$ & $47^{\circ} \mathrm{C}$ & $171,175,190$ \\
\hline DVIT4 & $(\mathrm{AAT})_{11}$ & AY056818 & $\begin{array}{l}\text { F: TCTTCAAAAATGTTACATGAT } \\
\text { R: TATACAATGAATGGTATCAATTC }\end{array}$ & $48^{\circ} \mathrm{C}$ & $\begin{array}{l}\text { 154, 156, 159, 162, } \\
164,(166)^{c}, 168\end{array}$ \\
\hline
\end{tabular}

aThe repeated motifs are those of the cloned allele (size of cloned allele is indicated in bold).

${ }^{\mathrm{b}}$ Annealing temperatures used in PCR amplification of the microsatellite loci were determined by subtracting $5^{\circ} \mathrm{C}$ from the lowest $\mathrm{T}_{\mathrm{m}}$ of the primer pair and subsequent PCR optimisation.

'The DVIT4 cloned allele was not observed in any of the genotypes in this study.

PCR products was performed using standard techniques on $5 \%$ polyacrylamide gels using $1 \times$ TBE buffer. After electrophoresis the gel was dried and exposed to X-ray film (Kodak).

\section{Genetic analysis of root and leaf samples}

Following Sunnucks et al (1997), alleles and genotypes are used with reference to single loci, whilst genotypic class refers to the alleles at all four loci. BIOSYS-1 (Swofford and Selander, 1981) was used to calculate the mean number of alleles per locus, observed direct count heterozygosity $\left(\mathrm{H}_{\mathrm{DC}}\right)$ and the expected heterozygosity $\left(\mathrm{H}_{\mathrm{E}}\right)$ based on the unbiased method (Nei, 1978). GENEPOP (Version 3.1) was used to calculate the exact test values for deviations from Hardy-Weinberg (Raymond and Rousset, 1995). The distribution of genotypic class across samples could not be compared using standard contingency tests due the small sample sizes. Instead, Monte Carlo tests were used to compare samples with the procedure from SPSS Version 10.0.

\section{Results}

The isolation of microsatellite loci proved difficult in grape phylloxera. It is unknown if the low numbers of microsatellites observed in this study is a characteristic common to other members of the Phylloxeridae. Differences in microsatellite density have been reported in other inveterbrate groups (Estoup and Angers, 1998). The four loci isolated were characterized for 361 insects from the 28 vineyards sampled. Based on these a total of 45 genotypic classes of $D$. vitifoliae were identified (Table 3 ).

For the root samples, all four loci were polymorphic for all samples, except for locus DVIT4 in the Nagambie and Orchard Hills regions (Table 4). Regions varied in the level of genetic heterogeneity, with the mean number of alleles observed per locus ranging from 1.8 in Nagambie and Orchard Hills to 4.3 in the Rutherglen region. The number of genotypic classes also varied between populations, from one in Nagambie, Orchard Hills and the King Valley to twenty-six in Rutherglen (Table 5).

Since only a few genotypic classes were found in the regions and because for all regions and loci there were significant departures from Hardy-Weinberg equilibrium (Table 4), the predominant mode of reproduction in grape phylloxera from roots appears to be parthenogenesis. In fact, the presence of a single highly heterozygous genotype in several regions indicates that parthenogenesis is often likely to be the sole method of reproduction.

The majority of the root samples were comprised of two genotypic classes, G1 and G4 $(55.8 \%$ and $12.6 \%$ of total root samples, respectively). G1 was the most widespread, occurring in four regions and in the majority of vineyards within those regions $(17 / 22)$. G4 was present in all vineyards sampled from Milawa and the King Valley and one vineyard in Glenrowan. These regions are adjacent in north east Victoria (Figure 1). Despite being widespread the G1 and G4 genotypic classes only cooccurred in one vineyard (GR-1). Of the other 29 genotypic classes identified from root samples, 25 were found in the Rutherglen region. Monte Carlo tests demonstrated significant differences among the regions $(P<0.001)$. In the Rutherglen region there was also significant heterogeneity among vineyards $(P<0.001)$.

Leaf gall samples in each of the three regions included many genotypic classes not sampled from the roots (Table 6) and Monte Carlo tests indicated significant $(P$ $<0.001)$ differences between samples in all three regions. In fact there was only limited overlap between genotypic classes sampled in roots and leaves. In Glenrowan, most root samples were G1 (Table 5) but this class was absent in leaf samples. Similarly, in Milawa most root samples were G4 (Table 5) including those from the area where leaf samples were obtained, but this class did not occur in the leaf samples. Leaf gall samples also differed significantly among the regions using a Monte Carlo test $(P$ $<0.001$ ).

Even though only a single female was sampled from a leaf gall and the founders of galls were expected to be the product of sexual reproduction, there were highly significant departures from Hardy-Weinberg equilibrium in these samples (Table 4). This suggests that gall samples do not arise directly from sexual reproduction.

\section{Discussion}

\section{Phylloxera reproduction}

Two genotypic classes, G1 and G4, predominated in root samples across different geographic regions and these 
Table 3 Definition of genotypic classes in Daktulosphaira vitifoliae based on the pattern of DNA fragment sizes at the four microsatellite loci identified in Table 2. NA refers to the non-amplification of a DNA fragment during PCR

\begin{tabular}{|c|c|c|c|c|}
\hline $\begin{array}{l}\text { Genotypic } \\
\text { Class }\end{array}$ & DVIT1 & DVIT2 & DVIT3 & DVIT4 \\
\hline G1 & $128 / 136$ & $259 / 289$ & $175 / 190$ & $159 / 159$ \\
\hline G2 & $134 / 136$ & $261 / 261$ & $175 / 175$ & $156 / 156$ \\
\hline G3 & $134 / 136$ & $259 / 261$ & $175 / 175$ & $156 / 156$ \\
\hline G4 & $128 / 136$ & $259 / 289$ & $175 / 190$ & $159 / 168$ \\
\hline G5 & $136 / 136$ & $259 / 259$ & $175 / 175$ & $156 / 159$ \\
\hline G6 & $134 / 136$ & $257 / 259$ & $175 / 175$ & $159 / 164$ \\
\hline G7 & $134 / 134$ & $259 / 259$ & $175 / 175$ & $156 / 164$ \\
\hline G8 & $134 / 134$ & $261 / 261$ & $175 / 175$ & $154 / 156$ \\
\hline G9 & $134 / 136$ & $257 / 259$ & $175 / 175$ & $156 / 159$ \\
\hline G10 & $134 / 138$ & $259 / 259$ & $175 / 175$ & $164 / 164$ \\
\hline G11 & $134 / 136$ & $259 / 259$ & $175 / 175$ & $156 / 164$ \\
\hline G12 & $134 / 136$ & $259 / 261$ & $175 / 175$ & $164 / 164$ \\
\hline G13 & $136 / 136$ & $259 / 259$ & $175 / 175$ & $156 / 164$ \\
\hline G14 & $136 / 136$ & $259 / 289$ & $175 / 175$ & $156 / 164$ \\
\hline G15 & $136 / 138$ & $259 / 259$ & $175 / 175$ & $164 / 164$ \\
\hline G16 & $128 / 136$ & $259 / 289$ & $175 / 175$ & $159 / 159$ \\
\hline G17 & $134 / 134$ & $259 / 261$ & $175 / 175$ & $156 / 164$ \\
\hline G18 & $134 / 134$ & $261 / 261$ & $175 / 175$ & $164 / 164$ \\
\hline G19 & $134 / 136$ & $259 / 259$ & $175 / 175$ & $164 / 164$ \\
\hline G20 & $132 / 136$ & $259 / 259$ & $175 / 175$ & $159 / 164$ \\
\hline G21 & $134 / 136$ & $261 / 289$ & $171 / 175$ & $164 / 164$ \\
\hline G22 & $136 / 136$ & $259 / 259$ & $175 / 175$ & $164 / 164$ \\
\hline G23 & $134 / 136$ & $259 / 261$ & $175 / 175$ & $159 / 164$ \\
\hline G24 & NA & $261 / 289$ & $175 / 175$ & $156 / 164$ \\
\hline G25 & $136 / 136$ & $259 / 259$ & $171 / 175$ & $156 / 164$ \\
\hline G26 & $134 / 134$ & $259 / 259$ & $175 / 175$ & $164 / 164$ \\
\hline G27 & $136 / 136$ & $261 / 261$ & $175 / 175$ & $164 / 164$ \\
\hline G28 & $134 / 136$ & $259 / 261$ & $175 / 175$ & $159 / 162$ \\
\hline G29 & $134 / 136$ & $261 / 261$ & $175 / 175$ & $164 / 164$ \\
\hline G30 & $134 / 134$ & $261 / 261$ & $175 / 175$ & $156 / 164$ \\
\hline G31 & $134 / 136$ & $261 / 261$ & NA & $156 / 164$ \\
\hline G32 & $134 / 136$ & $259 / 289$ & $175 / 175$ & $156 / 164$ \\
\hline G33 & $134 / 136$ & $257 / 259$ & $175 / 175$ & $156 / 156$ \\
\hline G34 & $134 / 136$ & $259 / 259$ & $175 / 175$ & $159 / 164$ \\
\hline G35 & $134 / 136$ & $259 / 259$ & $175 / 175$ & $156 / 156$ \\
\hline G36 & $134 / 136$ & $259 / 261$ & $175 / 175$ & $156 / 164$ \\
\hline G37 & $134 / 136$ & $259 / 289$ & $175 / 175$ & $156 / 156$ \\
\hline G38 & $134 / 134$ & $261 / 261$ & $175 / 175$ & $156 / 156$ \\
\hline G39 & $134 / 136$ & $259 / 261$ & $175 / 190$ & NA \\
\hline G40 & $136 / 136$ & $257 / 259$ & $175 / 175$ & $156 / 159$ \\
\hline G41 & $132 / 136$ & $259 / 259$ & $175 / 175$ & $164 / 164$ \\
\hline G42 & $132 / 136$ & $259 / 259$ & $175 / 175$ & $156 / 164$ \\
\hline G43 & $132 / 136$ & $259 / 259$ & $175 / 175$ & $156 / 159$ \\
\hline G44 & $132 / 136$ & $259 / 289$ & $175 / 175$ & $156 / 159$ \\
\hline G45 & $134 / 136$ & $259 / 259$ & $175 / 190$ & $159 / 164$ \\
\hline
\end{tabular}

genotypic classes were heterozygous at three of the four loci and all loci respectively. This indicates that the majority of the Australian populations of grape phylloxera are comprised of functionally parthenogenetic lineages. The heterozygous nature of these classes at several loci is consistent with previous observations of other primarily parthenogenetic aphid populations (Fuller et al, 1999; Simon et al, 1999). Reproduction by parthenogenesis in these lineages is supported by the absence of expected recombinant genotypes, such as individuals that are homozygous for the DVIT1 ${ }^{128}$ allele and significant deviation from Hardy-Weinberg equilibrium for all loci (Table 4).

G1 and G4 appear very similar and could only be differentiated by one allele at the DVIT4 locus (Table 3). The difference in size between these DVIT4 alleles was $9 \mathrm{bp}$, consistent with it being generated by the slip-strand mispairing (SSM) mechanism of microsatellite evolution, the DVIT4 locus containing a perfect tri-repeat unit (Eisen, 1999). This suggests G1 and G4 are derived from a common lineage. Only one other genotypic class, G16, may share a relatively recent origin with G1 and G4 (Table 3). No other derivatives of G1 were observed, despite being expected from the SSM model.

The traditional model of the life cycle of $D$. vitifoliae describes the leaf galling populations as originating each season from fundatrixes, which result from sexual recombination between individuals derived from the root populations. However, the data presented here indicate that this is not the primary life cycle strategy employed by populations of $D$. vitifoliae in Australian vineyards. Leaf galls were only observed in three of the 28 vineyards where grape phylloxera were sampled, and in those vineyards where both root and leaf populations co-exist there is little evidence that the leaf gall genotypes result from sexual recombination between the root genotypes sampled. For instance, consider the Glenrowan (GR-1) data where four genotypic classes were identified in root samples and five in leaf gall samples (Tables 5 and 6). Two of the root classes, G2 and G3, are identical to the most common leaf genotypic classes. Migration of clones between roots and leaves is a more probable reason for this observation than the generation of identical genotypes in leaf and root populations via independent sexual recombination events. The leaf gall genotypic class G38 could be the outcome of sex between individuals of the genotypic classes G2 and G3 (Table 3). However, additional genotypic classes comprised of DVIT1 ${ }^{136}$ homozygotes could also be expected to result from sex between G2 and G3 genotypic classes, but were not identified in any leaf gall sample.

The absence of G1 and G4 in the leaves in this region and the other regions suggests that these classes are restricted to the roots. Given that these classes are widespread and predominate in recently infested vineyards, they may well have biological attributes that preadapt them to colonizing new areas.

\section{Population structure}

Many genotypic classes were observed in the Rutherglen region root samples in contrast to other regions. This raises the issue of whether this diversity is a consequence of rare sexual recombination and/or multiple introductions possibly coupled with mutation. Recent sexual reproduction does not appear to be the major factor as identical genotypic classes occur in more than one vineyard. If the genotypes were the result of recombination followed by expansion of lineages by parthenogenesis, the majority of samples of any one genotypic class should be found within the same location in the presence of related recombinant genotypes, particularly as grape phylloxera has limited dispersal under Australian conditions (King and Buchanan, 1986). However, of the 15 genotypic classes sampled multiple times, nine were found in more than one vineyard (Table 5). The likelihood of these identical genotypic classes arising in separate locations via independent sexual recombinant events is low, unless there was extremely rare sex with sexual offspring unable to compete successfully against parthenogenic lineages (Lynch, 1984; Wilson et al, 1999; Peck and Waxman, 2000). More intensive intra-vineyard studies 
Table 4 Analysis of genetic variation, including deviations from Hardy-Weinberg equilibrium, in Daktulosphaira vitifoliae root and leaf populations

\begin{tabular}{|c|c|c|c|c|c|c|c|c|c|c|}
\hline \multirow[t]{2}{*}{ Locus } & & \multicolumn{6}{|c|}{ Root samples by region } & \multicolumn{3}{|c|}{ Leaf samples by vineyard } \\
\hline & & Rutherglen & Milawa & Glenrowan & King Valley & Orchard Hills & Nagambie & $R U-13$ & $M L-1$ & GR-1 \\
\hline DVIT1 & $\begin{array}{l}\text { Alleles } \\
\mathrm{H}_{\mathrm{DC}} \\
\mathrm{H}_{\mathrm{E}} \\
\mathrm{P} \\
\mathrm{SLP}\end{array}$ & $\begin{array}{l}4 \\
0.633 \\
0.644 \\
0.000 \\
0.730\end{array}$ & $\begin{array}{l}4 \\
0.952 \\
0.554 \\
0.003 \\
1\end{array}$ & $\begin{array}{l}3 \\
0.968 \\
0.624 \\
0.000 \\
0.540\end{array}$ & $\begin{array}{l}2 \\
1 \\
0.520 \\
0.002 \\
-\end{array}$ & $\begin{array}{l}2 \\
1 \\
0.524 \\
0.007 \\
-\end{array}$ & $\begin{array}{l}2 \\
1 \\
0.504 \\
0.000 \\
-\end{array}$ & $\begin{array}{l}2 \\
0.862 \\
0.494 \\
0.000 \\
0.045\end{array}$ & $\begin{array}{l}3 \\
0.879 \\
0.595 \\
0.000 \\
0.710\end{array}$ & $\begin{array}{l}2 \\
0.947 \\
0.503 \\
0.000 \\
0.427\end{array}$ \\
\hline DVIT2 & $\begin{array}{l}\text { Alleles } \\
\mathrm{H}_{\mathrm{DC}} \\
\mathrm{H}_{\mathrm{E}} \\
\mathrm{P} \\
\text { SLP }\end{array}$ & $\begin{array}{l}4 \\
0.477 \\
0.563 \\
0.000 \\
0.014\end{array}$ & $\begin{array}{l}3 \\
0.905 \\
0.528 \\
0.006 \\
1\end{array}$ & $\begin{array}{l}3 \\
0.871 \\
0.634 \\
0.000 \\
0.650\end{array}$ & $\begin{array}{l}2 \\
1 \\
0.524 \\
0.003 \\
-\end{array}$ & $\begin{array}{l}2 \\
1 \\
0.524 \\
0.006 \\
-\end{array}$ & $\begin{array}{l}2 \\
1 \\
0.504 \\
0.000 \\
-\end{array}$ & $\begin{array}{l}3 \\
0.231 \\
0.211 \\
1 \\
0.272\end{array}$ & $\begin{array}{l}2 \\
0.091 \\
0.089 \\
1 \\
1\end{array}$ & $\begin{array}{l}4 \\
0.667 \\
0.472 \\
0.000 \\
0.300\end{array}$ \\
\hline DVIT3 & $\begin{array}{l}\text { Alleles } \\
\mathrm{H}_{\mathrm{DC}} \\
\mathrm{H}_{\mathrm{E}} \\
\mathrm{P} \\
\mathrm{SLP}\end{array}$ & $\begin{array}{l}3 \\
0.256 \\
0.228 \\
0.686 \\
-\end{array}$ & $\begin{array}{l}2 \\
0.850 \\
0.501 \\
0.014 \\
-\end{array}$ & $\begin{array}{l}2 \\
0.733 \\
0.472 \\
0.002 \\
1\end{array}$ & $\begin{array}{l}2 \\
1 \\
0.520 \\
0.002 \\
-\end{array}$ & $\begin{array}{l}2 \\
1 \\
0.524 \\
0.008 \\
-\end{array}$ & $\begin{array}{l}2 \\
1 \\
0.504 \\
0.000 \\
-\end{array}$ & $\begin{array}{l}1 \\
- \\
- \\
- \\
-\end{array}$ & $\begin{array}{l}2 \\
0.091 \\
0.088 \\
1 \\
1\end{array}$ & $\begin{array}{l}1 \\
- \\
- \\
- \\
-\end{array}$ \\
\hline DVIT4 & $\begin{array}{l}\text { Alleles } \\
\mathrm{H}_{\mathrm{DC}} \\
\mathrm{H}_{\mathrm{E}} \\
\mathrm{P} \\
\text { SLP }\end{array}$ & $\begin{array}{l}5 \\
0.471 \\
0.668 \\
0.000 \\
0.027\end{array}$ & $\begin{array}{l}4 \\
1 \\
0.585 \\
0.000 \\
1\end{array}$ & $\begin{array}{l}3 \\
0.032 \\
0.442 \\
0.000 \\
0.087\end{array}$ & $\begin{array}{l}2 \\
1 \\
0.520 \\
0.002 \\
-\end{array}$ & $\begin{array}{l}1 \\
- \\
- \\
- \\
-\end{array}$ & $\begin{array}{l}1 \\
- \\
- \\
- \\
-\end{array}$ & $\begin{array}{l}2 \\
0.646 \\
0.503 \\
0.024 \\
0.471\end{array}$ & $\begin{array}{l}3 \\
0.750 \\
0.641 \\
0.004 \\
1\end{array}$ & $\begin{array}{l}1 \\
- \\
- \\
- \\
-\end{array}$ \\
\hline All loci & $\begin{array}{l}\text { Alleles } \\
\text { (SE) } \\
\text { n (SE) } \\
\mathrm{PL} \\
\mathrm{H}_{\mathrm{DC}} \text { (SE) } \\
\mathrm{H}_{\mathrm{E}} \text { (SE) } \\
\mathrm{P} \\
\mathrm{SLP}(\mathrm{n})\end{array}$ & $\begin{array}{l}4.3(0.5) \\
\\
85.8(2.7) \\
100 \\
0.460(0.077) \\
0.526(0.102) \\
0.00 \\
0.011(26)\end{array}$ & $\begin{array}{l}3.3(0.5) \\
20.3(0.5) \\
100 \\
0.927(0.032) \\
0.542(0.018) \\
0.000 \\
1(4)\end{array}$ & $\begin{array}{l}2.75(0.25) \\
\\
30.8(0.3) \\
100 \\
0.651(0.212) \\
0.543(0.05) \\
0.000 \\
0.540(4)\end{array}$ & $\begin{array}{l}2.0(0.0) \\
12.5(0.5) \\
100 \\
1(0.0) \\
0.521(0.001) \\
0.000 \\
-(1)\end{array}$ & $\begin{array}{l}1.8(0.3) \\
11.0(0.0) \\
75 \\
0.750(0.25) \\
0.393(0.131) \\
0.000 \\
-(1)\end{array}$ & $\begin{array}{l}1.8(0.3) \\
67.0(0.0) \\
75 \\
0.750(0.25) \\
0.378(0.126) \\
0.000 \\
-(1)\end{array}$ & $\begin{array}{l}2(0.4) \\
\\
65.0(0.0) \\
75 \\
0.435(0.195) \\
0.302(0.121) \\
0.000 \\
0.111(8)\end{array}$ & $\begin{array}{l}2.8(0.3) \\
32.8(0.3) \\
50 \\
0.453(0.211) \\
0.353(0.153) \\
0.000 \\
0.953(9)\end{array}$ & $\begin{array}{l}2(0.71) \\
57(0.0) \\
50 \\
0.404(0.240) \\
0.244(0.141) \\
0.000 \\
0.392(5)\end{array}$ \\
\hline
\end{tabular}

Alleles $=$ number of alleles; $\mathrm{H}_{\mathrm{DC}}=$ direct-count heterozygosity; $\mathrm{H}_{\mathrm{E}}=$ expected heterozygosity (unbiased estimate); $P=P$-value of the HardyWeinberg exact test; SLP $=P$-value of the Hardy-Weinberg exact test using only one individual per genotype (based on the rationale of Sunnucks et al, 1997); $n=$ sample size; $\mathrm{PL}=$ percentage of polymorphic loci (based on 0.95 criterion); $\mathrm{SE}=$ standard error.

within the Rutherglen region should help to ascertain if rare sex and recombinant genotypic classes do indeed occur.

Another explanation for the relatively high level of genetic diversity in the Rutherglen region involves multiple introductions of clones of polyphyletic origins. Historical records of grapevine movement suggest the Rutherglen region was a site of extensive introductions of grapevine material from Europe during the late-18th and early-19th Centuries (reviewed in Corrie et al, 1997). The insect was widespread in Europe during this time and several genotypes could have been transported to Australia on grapevine material. Recent AFLP studies have demonstrated a high degree of genetic variability within European D. vitifoliae populations (Forneck et al, 2000). With the detection of downy mildew (Plasmopara viticola) in Australia in 1917, strict quarantine restrictions were implemented on imported grapevine material (de Castella and Brittlebank, 1917). Consequently, new grape phylloxera introductions into Australia would be extremely unlikely.

However, this scenario is inconsistent with the low diversity in other regions in Australia, which have long viticultural histories. Continuous viticulture has occurred in Nagambie since $D$. vitifoliae was first observed during the 1890s, and in Glenrowan and Milawa since the insect was observed during the 1920s, providing an opportunity for founder population continuation. Movement of vine material has occurred between these regions and the
Rutherglen region over the last 80 years. Until 1986, all these regions were included in one large quarantine district enabling the free movement of grapevine material and consequently any grape phylloxera present on this material (Buchanan, 1987). Other factors therefore appear to be influencing the frequency and geographic distribution of clones.

Host specialisation has been implicated in the maintenance of high intra-population variation of some aphid species (De Barro et al, 1995; Hales et al, 1997). Previous studies have implied $D$. vitifoliae populations do differ in their ability to inhabit various Vitis genotypes (Granett et al, 1985; King and Rilling, 1985), although DNA typing data collected so far suggest a limited association of host plant with particular genetic strains in both native and cultivated vineyard situations (Downie, 2000; Forneck et al, 2000).

A difference in clonal heterogeneity over an environmental range has been described in other organisms including unisexual fish (Vrijenhoek and Pfeiler, 1997) and snails (Fox et al, 1996). In these organisms, the frozen niche variation model has been invoked to help explain the observation that clonal lineages could coexist in space (Vrijenhoek, 1979). Essentially the model suggests that clonal diversity is maintained by selection due to environmental variation with occasional sex, resulting in 'specialised' clones adapted to particular niches. Decreased clonal diversity would then be expected in environments with reduced variation. However, the 
Table 5 Genotypic classes of Daktulosphaira vitifoliae sourced from the roots

\begin{tabular}{|c|c|c|c|c|c|c|c|c|c|c|c|c|c|c|c|c|c|c|c|c|c|c|c|}
\hline Geographic Region & Vineyard Code & G1 & G2 & G3 & G4 & G5 & G6 & G7 & G8 & G9 & G10 & G11 & G12 & G13 & G14 & G15 & G16 & G17 & G18 & G19 & G20 & G21-G31 & Total \\
\hline \multirow[t]{3}{*}{ Glenrowan } & GR-1 & 2 & 3 & 4 & 1 & - & - & - & - & - & - & - & - & - & - & - & - & - & - & - & - & - & 10 \\
\hline & GR-3 & 8 & - & - & - & - & _ & - & _ & - & - & _ & _ & - & - & - & _ & - & - & _ & - & _ & 8 \\
\hline & GR-4 & 11 & - & 1 & - & - & - & - & - & - & - & - & - & - & - & - & - & - & - & - & - & - & 12 \\
\hline Glenrowan Total & & 21 & 3 & 5 & 1 & - & - & - & - & - & - & - & - & - & - & - & - & - & - & - & - & - & 30 \\
\hline \multirow[t]{4}{*}{ King Valley } & $\mathrm{CH}-1$ & - & - & - & 4 & - & - & - & - & - & - & - & - & - & - & - & - & - & - & - & - & - & 4 \\
\hline & WF-1 & - & - & - & 2 & - & - & - & - & - & - & - & - & - & - & - & - & - & - & - & - & - & 2 \\
\hline & WL-1 & - & - & - & 4 & - & - & - & - & - & - & - & - & - & - & - & - & - & - & - & - & - & 4 \\
\hline & WL-2 & - & - & - & 2 & - & - & - & - & - & - & - & - & - & - & - & - & - & - & - & - & - & 2 \\
\hline King Valley Total & & - & - & - & 12 & - & - & - & - & - & - & - & - & - & - & - & - & - & - & - & - & - & 12 \\
\hline \multirow[t]{2}{*}{ Milawa } & ML-1 & - & - & - & 8 & 1 & 1 & - & - & - & - & - & - & - & - & - & - & - & - & - & 1 & - & 11 \\
\hline & ML-3 & - & - & - & 5 & - & - & - & - & - & - & - & - & - & - & - & - & - & - & - & - & - & 5 \\
\hline Milawa Total & & - & - & - & 13 & 1 & 1 & - & - & - & - & - & - & - & - & - & - & - & - & - & 1 & - & 16 \\
\hline \multirow[t]{5}{*}{ Nagambie } & NA-1 & 28 & - & - & - & - & - & - & - & - & - & - & - & - & - & - & - & - & - & - & - & - & 28 \\
\hline & NA-2 & 25 & - & - & - & - & - & - & - & - & - & - & - & - & - & - & - & - & - & - & - & - & 25 \\
\hline & NA-3 & 4 & - & - & - & - & - & - & - & - & - & - & - & - & - & - & - & - & - & - & - & - & 4 \\
\hline & NA-5 & 5 & - & - & - & - & - & - & - & - & - & - & - & - & - & - & - & - & - & - & - & - & 5 \\
\hline & NA-6 & 4 & - & - & - & - & - & - & - & - & - & - & - & - & - & - & - & - & - & - & - & - & 4 \\
\hline Nagambie Total & & 66 & - & - & - & - & - & - & - & - & - & - & - & - & - & - & - & - & - & - & - & - & 66 \\
\hline \multirow[t]{3}{*}{ Orchard Hills } & $\mathrm{OH}-1$ & 3 & - & - & - & - & - & - & - & - & - & - & - & - & - & - & - & - & - & - & - & - & 3 \\
\hline & $\mathrm{OH}-2$ & 4 & - & - & - & - & - & - & - & - & - & - & - & - & - & - & - & - & - & - & - & - & 4 \\
\hline & $\mathrm{OH}-3$ & 3 & - & - & - & - & - & - & - & - & - & - & - & - & - & - & - & - & - & - & - & - & 3 \\
\hline Orchard Hills Total & & 10 & - & - & - & - & - & - & - & - & - & - & - & - & - & - & - & - & - & - & - & - & 10 \\
\hline \multirow[t]{11}{*}{ Rutherglen } & RU-1 & 1 & - & - & - & - & - & 2 & - & - & - & - & 1 & - & - & 1 & - & - & 1 & 2 & - & 8 & 16 \\
\hline & RU-2 & - & - & - & - & - & - & 3 & - & - & - & 1 & - & - & - & - & - & - & - & - & - & 1 & 5 \\
\hline & RU-3 & - & - & - & - & - & - & 1 & - & - & - & 2 & 2 & - & - & 1 & - & 1 & - & - & 1 & - & 8 \\
\hline & RU-4 & - & - & - & - & - & - & - & - & - & - & - & - & - & - & - & - & - & - & - & - & - & 2 \\
\hline & RU-5 & 2 & - & - & - & - & - & - & - & 5 & - & - & - & - & - & - & - & - & - & - & - & - & 5 \\
\hline & RU-6 & - & - & - & - & - & - & - & - & - & 3 & - & - & 3 & - & - & - & - & - & - & - & 1 & 11 \\
\hline & RU-7 & 2 & - & - & - & - & - & - & - & - & - & - & - & - & - & - & - & - & - & - & - & - & 2 \\
\hline & RU-8 & - & - & - & - & - & - & - & 4 & - & - & - & - & - & - & - & - & - & - & - & - & - & 4 \\
\hline & RU-9 & - & - & - & - & - & - & - & 1 & - & 1 & - & - & - & - & - & - & - & - & - & - & - & 2 \\
\hline & RU-13 & 5 & - & - & - & - & - & - & - & - & - & 1 & - & - & 2 & - & - & - & - & - & - & - & 8 \\
\hline & RU-15 & 4 & - & - & - & - & - & - & - & - & - & - & - & - & - & - & 2 & 1 & 1 & - & - & 1 & 9 \\
\hline Rutherglen Total & & 18 & - & - & - & - & - & 6 & 5 & 5 & 4 & 4 & 3 & 3 & 2 & 2 & 2 & 2 & 2 & 2 & 1 & $11^{a}$ & 72 \\
\hline Grand Total & & 115 & 3 & 5 & 26 & 1 & 1 & 6 & 5 & 5 & 4 & 4 & 3 & 3 & 2 & 2 & 2 & 2 & 2 & 2 & 2 & 11 & 206 \\
\hline
\end{tabular}

${ }^{a}$ Genotypic classes sampled only once in the Rutherglen district (G21-G31) are represented as a pooled total.

Table 6 Genotypic classes of Daktulosphaira vitifoliae sourced from leaf galls. Bold type indicates genotypes sampled from both the leaf and root components of the grapevine

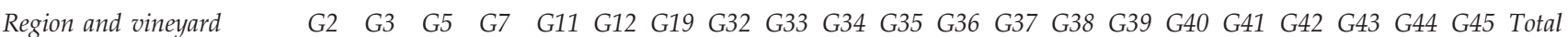
code

$\begin{array}{llllllllllllllllllllllll}\text { Glenrowan (GR-1) } & \mathbf{1 6} & \mathbf{3 6} & - & - & - & - & - & - & 1 & - & - & - & 1 & 3 & - & - & - & - & - & - & - & 57 \\ \text { Milawa (ML-1) } & - & - & \mathbf{3} & - & - & - & - & - & - & 10 & - & - & - & - & 1 & 1 & 8 & 3 & 5 & 1 & 1 & 33 \\ \text { Rutherglen (RU-13) } & - & - & - & \mathbf{9} & \mathbf{2 5} & \mathbf{7} & \mathbf{6} & 2 & - & - & 10 & 4 & 2 & - & - & - & - & - & - & - & - & 65 \\ \text { Total } & \mathbf{1 6} & \mathbf{3 6} & \mathbf{3} & \mathbf{9} & \mathbf{2 5} & \mathbf{7} & \mathbf{6} & \mathbf{2} & 1 & 10 & 10 & 4 & 3 & 3 & 1 & 1 & 8 & 3 & 5 & 1 & 1 & 155\end{array}$

results of our study are inconsistent with this model at least in terms of heterogeneity associated with vine host. For example, in the vineyard RU-3 only one vine host was present $(A x R \# 1)$ but various genotypic classes of grape phylloxera were found.

The occurrence of G1 over a broad geographic range suggests that this clone may be a 'general purpose genotype' (Lynch, 1984). Clones with low fitness variance for a large range of biotic and environmental factors may result from selection on populations with a long history of clonal reproduction. While these generalised genotypes may be out competed in the short term in niche environments by more specialised clonal or sexual lineages, over time they will be present over the broadest geographic range. Nevertheless, grape phylloxera is an introduced species to Australia and the genotypic pattern could be the result of founder effects rather than the biological attributes of clonal lineages. A more comprehensive study on the genetic relationship between grape phylloxera clones and their relative fitness will help to 
resolve the potential contribution of the above models to clonal persistence, composition and distribution.

\section{Applied significance}

The predominance of parthenogenetic reproduction on the root system has implications for the use of rootstocks. Increasingly the durability of Vitis host resistance in commercial viticulture has been questioned, with the suggestion that more virulent strains of grape phylloxera may arise through the processes of evolution and selection (Granett et al, 1985; Bleser and Rühl, 1997). The absence of sexual offspring in the root gall populations may reduce the risk of resistance adaptation in the field, although somatic mutation could still have an impact on resistance evolution.

With regards to quarantine, the lack of recombinant genotypes on the roots indicates that alates, and consequently sexuals, are not likely to be a source of spread of this insect. Likewise, leaf galls do not appear to be the major quarantine risk, since there appears to be little interaction between leaf and root populations (ie, insects from leaf galls rarely establish on roots). Indeed the data indicate that G1 and G4 genotypes should be the focus of quarantine studies, being the most widespread of the genotypic classes. The parthenogenetic root gall insects appear to be of higher quarantine risk than the alates, sexual forms, or those from leaf galls.

\section{Acknowledgements}

We thank Dr Steven Frankenburg, Dr Janet Hatt and Stephen Winnall for excellent assistance in the field and laboratory, and numerous colleagues for assistance in collection of samples, in particular Rebecca Dunstone, Shane Hackett and Megan Hill. The cooperation of the vineyard owners involved was much appreciated. Thanks to Dr Michael Goodismann, Tracy Reynolds, and two anonymous reviewers for comments on the manuscript. Financial support was provided by the Phylloxera and Grape Industry Board of South Australia, the Department of Natural Resources and Environment, and the Australian Research Council via their SPIRT and Special Research Centre Programs.

\section{References}

Adcock GH (1902). The History of Phylloxera in Victoria, Department of Agriculture Victoria: Melbourne, pp 79-83.

Ausubel F, Brent R, Kingston R, Moore D, Seidman JG, Smith JA et al (1996). Current Protocols in Molecular Biology. John Wiley and Sons: Brooklyn, New York.

Bleser E, Rühl E (1997). Schädling gibt noch viele Rätsel auf, Das Deutsche Weinmagazin, 10-17 Mai, pp 22-26.

Buchanan GA (1987). The distribution of grape phylloxera, Daktulosphaira vitifoliae (Fitch), in central and north-eastern Victoria. Aust J Exper Agric 27: 591-593.

Buchanan GA (1990). The distribution, biology and control of grape phylloxera, Daktulosphaira vitifolii (Fitch), in Victoria. PhD thesis, La Trobe University, Melbourne.

Corrie AM, Buchanan GA, van Heeswijck R (1997). DNA typing of populations of phylloxera (Daktulosphaira vitifoliae (Fitch)) from Australian vineyards. Aust J Grape Wine Res 3: 50-56.

Davidson WM, Nougaret RL (1921). The grape phylloxera in California. United States Department of Agriculture (Washington), pp 1-28.

De Barro PJ, Sherratt TN, David O, Maclean N (1995). An inves- tigation of the differential performance of clones of the aphid Sitobion avenae on two host species. Oecologia 104: 379-385.

de Castella F, Brittlebank C (1917). Note on Downy Mildew. J Agric (Victoria) 15: 685-700.

Dedryver CA, Le Gallic JF, Gauthier JP (1998). Life cycle of the cereal aphid Sitobion avenae F.: polymorphism and comparison of life history traits associated with sexuality. Ecol Entomol 23: 123-132.

Downie D (2000). Patterns of genetic variation in native grape phylloxera on two sympatric host species. Mol Ecol 9: 505-514.

Downie D, Granett J (1998). A life cycle variation in Grape Phylloxera Daktulosphaira vitifoliae (Fitch). Southwest Entomol 23: $11-16$.

Eisen JA (1999). Mechanistic basis for microsatellite instability. In: Goldstein DB, Schlötterer C (eds) Microsatellites: Evolution and Application, Oxford University Press: Oxford, pp 35-48.

Estoup A, Angers B (1998). Microsatellites and minisatellites for molecular ecology: theoretical and empirical considerations. In: Carvalho GR (ed) Advances in Molecular Ecology, IOS Press: Amsterdam, pp 55-86.

Fletcher MJ (1984). The occurance of phylloxera in New South Wales. In: Buchanan GA, Amos TA (eds) The Biology, Quarantine and Control of Grape Phylloxera in Australia and New Zealand, Victorian Deparrment of Agriculture: Rutherglen, Victoria, Australia, p 78.

Forneck A, Walker MA, Blaich R (2000). Genetic structure of an introduced pest, grape phylloxera (Daktulosphaira vitifoliae Fitch), in Europe. Genome 43: 669-678.

Forneck A, Walker MA, Blaich R (2001). An in vitro assessment of phylloxera (Daktulosphaira vitifoliae Fitch) (Homoptera Phylloxeridae) life cycle. J Appl Entomol 125: 443-447.

Fox JA, Dybdahl MF, Jokela J, Lively CM (1996). Genetic structure of coexisting sexual and clonal subpopulations in a freshwater snail (Potamopyrgus antipodarum). Evolution 50: 15411548.

Fuller S, Chavigny P, Lapchin L, Vanlerberghe-Masutti F (1999). Variation in clonal diversity in glasshouse infestations of the aphid, Aphis gossypii Glover in Southern France. Mol Ecol 8: 1867-1877.

Granett J, Timper P, Lider LA (1985). Grape Phylloxera (Daktulosphaira vitifoliae) (Homoptera: Phylloxeridae) Biotypes in California. J Econ Entomol 78: 1463-1467.

Granett J, Walker MA, Kocsis L, Omer AD (2001). Biology and management of grape phylloxera. Ann Rev Entomol 46: 387412.

Hales DH, Tomiuk J, Wöhrmann K, Sunnucks P (1997). Evolutionary and genetic aspects of aphid biology: a review. Eur I Entomol 94: 1-55.

Kellow AV, Corrie AM, van Heeswijck R (1999). Surface sterilisation of phylloxera eggs for investigating grapevine-phylloxera interactions in tissue culture. Aust J Grape Wine Res 5: $27-28$.

King PD, Buchanan GA (1986). The dispersal of phylloxera crawlers and spread of phylloxera infestations in New Zealand and Australian vineyards. Am J Enol Viticult 37: 26-33.

King PD, Rilling G (1985). Variations in the galling reaction of grapevines: Evidence of different phylloxera biotypes and clonal reaction to phylloxera. Vitis 24: 32-42.

Lin H, Walker MA (1996). Extraction of DNA from a single egg of grape phylloxera (Daktulosphaira vitifoliae Fitch) for use in RAPD testing. Vitis 35: 87-89.

Lynch M (1984). Destabilizing hybridization, general-purpose genotypes and geographic parthenogenesis. Quart Rev Biol 59: 257-290.

Moran N (1992). The evolution of aphid life cycles. Ann Rev Entomol 37: 321-348.

Nei M (1978). Estimation of average heterozygosity and genetic distance from a small number of individuals. Genetics 89: 583-590.

Ordish G (1974). The Great Wine Blight. Sidgewick and Jackson: London. 
Peck JR, Waxman D (2000). What's wrong with a little sex? J Evol Biol 13: 63-69.

Raymond M, Rousset F (1995). GENEPOP (version 1.2): a population genetics software for exact tests and ecumenicism. J Hered 86: 248-249.

Simon J, Baumann S, Sunnucks P, Hebert P, Pierre J, Le Gallic JF et al. (1999). Reproductive mode and population genetic structure of the cereal aphid Sitobion avenae studied using phenotypic and microsatellite markers. Mol Ecol 8: 551-545.

Sunnucks P, de Barro PJ, Lushai G, Maclean N, Hales D (1997). Genetic structure of an aphid studied using microsatellites: cyclic parthenogenesis, differentiated lineages and host specialization. Mol Ecol 6: 1059-1073.

Sunnucks P, England PR, Taylor AC, Hales DF (1996). Microsatellite and chromosome evolution of parthenogenetic Sitobion Aphids in Australia. Genetics 144: 747-756.
Swofford DL, Selander RB (1981). BIOSYS-1: A FORTRAN program for the comprehensive analysis of electrophoretic data in population genetics and systematics. J Hered 72: 281-283.

Vrijenhoek RC (1979). Factors affecting clonal diversity and coexistance. Am Zool 19: 787-797.

Vrijenhoek RC, Pfeiler E (1997). Differential survival of sexual and asexual Poeciliopsis during environmental stress. Evolution 51: 1593-1600.

Walsh P, Metzger D, Higushi R (1991). Chelex ${ }^{\circledR} 100$ as a medium for simple extraction of DNA for PCR-based typing from forensic material. Biotechniques 10: 506-513.

Wilson A, Sunnucks P, Hales D (1999). Microevolution, low clonal diversity and genetic affinities of parthenogenetic Sitobion aphids in New Zealand. Mol Ecol 8: 1655-1666. 